\title{
DEFLECTING ROOTS NEAR SIDEWALKS
}

\section{Edward F. Gilman}

\begin{abstract}
Concrete sidewalks $10 \mathrm{~cm}$ (4 in) thick measuring $1.2 \mathrm{~m}$ ( $4.5 \mathrm{ft}$ ) wide by $5 \mathrm{~m}$ (16.5 ft) long were installed in spring 1996 with and without barriers designed to deflect roots. Forty-eight Platanus occidentalis from \#15 containers were planted $0.75 \mathrm{~m} \mathrm{(30}$ in) from sidewalks and irrigated regularly to encourage rapid growth. Identical studies were installed on one well-drained and one poorly drained site located about $18 \mathrm{~km}$ (11.2 miles) apart. Barriers included $30 \mathrm{~cm}$ (12 in) deep DeepRoot, Biobarrier®, polyethylene (6 mil), a clean gravel layer ( $15 \mathrm{~cm}$ [6 in] deep; 2 to $3 \mathrm{~cm}$ [0.8 to $1.2 \mathrm{in}$ ] diameter) under the walk, and a control without a barrier. Roots were excavated 8 years after planting. No roots grew in the gravel in the well-drained site, resulting in a significantly deeper root system (19 cm [7.6 in]) under the walks than all other treatments (11 cm [4.4 in]). Vertical root barriers did not increase root depth compared to the control on the welldrained soil. Gravel under the walk and Biobarrier were most effective on poorly drained soil. DeepRoot was the least effective vertical barrier on the poorly drained site; Biobarrier was the most effective. Treatments had no effect on diameter of roots growing under the sidewalks. Roots deflected by the vertical barriers were forced deeper into the soil, but many returned to the surface by the time they reached the opposite side of the walk. Gravel under the sidewalk appears to hold promise for reducing sidewalk damage, especially on well-drained sites.
\end{abstract}

Key Words. Gravel; root depth; root diameter; urban design; vertical root barriers.

Roots growing under concrete walks have been associated with extensive sidewalk damage (Rajani 2002), although one study casts doubt on the cause of sidewalk damage (Sydnor et al. 2000). Certain tree species and cultivars cause less sidewalk damage by developing a small trunk flare (Wagar and Barker 1983), maturing at a small size (Costello and Jones 2003), developing a relatively deep root system (Francis et al. 1996), and other factors (Randrup et al 2001). Nursery production method may also affect surface rooting (Marshall and Gilman 1997) and, therefore, damage potential.

There are many observations of root damage to sidewalks (Costello and Jones 2003); however, there are only a few controlled studies of newly planted tree response to physical barriers designed to deflect roots (Wagar 1985; Barker 1995a, 1995b; Peper 1998). Physical and chemical vertical barriers deflect roots downward or laterally (Randrup et al 2001). Few roots grow through the commercial barriers (Kopinga 1994). Wagar (1985) showed that a plastic barrier deflected roots to deeper soil layers; however, after growing under the barrier, roots in a poorly drained clay soil quickly grew back to the soil surface. The barrier was most effective in the parts of the field containing well-drained soil, where roots returned to the surface more gradually. Gilman (1996) and Costello et al. (1997) also found that roots often return to the soil surface after growing under vertical barriers. Barker (1995a, 1995b) showed that in an alluvial, welldrained, silty clay loam soil, roots deflected down by a polyethylene plastic sheet did not grow up toward the soil surface within $1 \mathrm{~m}(3.3 \mathrm{ft})$ of the barrier.

Other reports indicate that barriers can deflect roots growing from pruned roots on established trees; the authors speculated that this could potentially reduce damage to sidewalks (Wagar and Barker 1993). Approximately 25\% of the nearly 200 urban forestry programs using root barriers in California, U.S., report them to be effective in reducing sidewalk damage; another $25 \%$ report that they are partially effective (Bernhardt and Swiecki 1993). Therefore, about half those that tried barriers question their usefulness. Most responding to the survey said species selection was nearly 90\% effective in reducing sidewalk damage, with smallstatured trees less damaging than large-growing ones.

Kopinga (1994) in the Netherlands showed that gravel under asphalt bicycle paths reduced rooting directly under the path and extended its life. Others suggest that a gravel sub-base can prevent roots from growing under walks by creating an air environment too dry for root growth (Coder 1998). The purpose of this study was to evaluate effectiveness of root barriers and gravel near and under sidewalks on well-drained soil and poorly drained soil.

\section{MATERIALS AND METHODS}

Sidewalk sections $10 \mathrm{~cm}$ (4 in) thick measuring $4.6 \times 1.2 \mathrm{~m}$ $(16.5 \times 4.5 \mathrm{ft})$ were installed in USDA (1990) hardiness zone 8 in Gainesville, Florida, U.S., May 1996, on a well-drained (Millhopper fine sand ([loamy, siliceous, hyperthermic Grossarenic Paleudults]) site and a poorly drained site (Arrendondo fine sand). About $8 \mathrm{~cm}$ (3.2 in) of soil was removed from each $4.6 \times 1.2 \mathrm{~m}(16.5 \times 4.5 \mathrm{ft})$ area before pouring concrete sidewalks. Sidewalks were not reinforced. Sidewalk sections were placed $9.2 \mathrm{~m}(30.4 \mathrm{ft})$ apart in a row

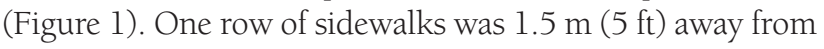
and parallel to a second row, with a tree planted between them. A third row was $1.5 \mathrm{~m}(5 \mathrm{ft})$ away from and parallel to a fourth row, with a tree planted between them. Each row of sidewalks acted as a replicate. Treatments, including no sidewalk control, were randomly arranged within a row. Experimental design was a randomized complete block design on 2 soil types $\times 6$ treatments $\times 4$ replicates $=48$ trees. 


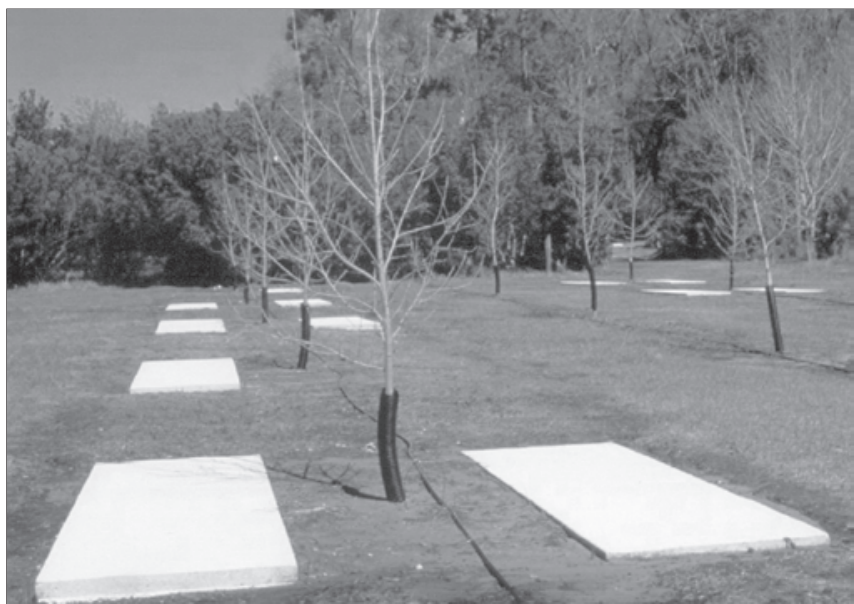

Figure 1. One tree was planted between sidewalk sections with various vertical root barriers on the tree side of the walk, or gravel under the walk, or a control without a barrier.

Six treatments were installed at each site, including (1) no sidewalk and no root barrier, (2) sidewalk and no root barrier, (3) Biobarrier® $30 \mathrm{~cm}$ (12 in) deep installed vertically next to sidewalk, (4) DeepRoot $30 \mathrm{~cm}$ (12 in) deep installed vertically next to sidewalk, (5) polyethylene (6 mil) plastic installed vertically next to sidewalk, and (6) a clean gravel (2.5 cm [1 in] diameter without fines or soil) layer 15 $\mathrm{cm}$ (6 in) deep under the sidewalk. Vertical barriers were installed in an $8 \mathrm{~cm}$ ( $3.2 \mathrm{in}$ ) wide trench about $2.5 \mathrm{~cm}$ ( 1 in) from the concrete edge on the side of the walk where the trees were planted. The top of the vertical barriers was about $2.5 \mathrm{~cm}$ ( 1 in) above the soil surface. Gravel was spread after cutting the grade $22 \mathrm{~cm}$ (9.2 in) with a frontend loader blade. Concrete was poured directly over gravel; concrete did not penetrate between gravel pieces.

Sycamore (Platanus occidentalis L.) was selected because it grows fast and can develop many large surface roots (Gilman 1996; Costello and Jones 2003). Trees were planted $0.75 \mathrm{~m}$ (30 in) from the sidewalks in May 1996 from \#15 containers, with the topmost root in the root ball at the soil surface. Irrigation and fertilizer were applied regularly to encourage rapid growth. In an effort to keep tree growth rates similar on both soil types, irrigation frequency was reduced on one soil type when trunk diameter growth at that site was greater than the other site. Mulch was maintained in the $4.6 \times 1.2 \mathrm{~m}(16.5 \times 4.5 \mathrm{ft})$ soil area between sidewalks. Weeds were controlled in this area with periodic applications of glyphosate. Grass was regularly mowed in other portions of the plot.

In November 2003, a trench $30 \mathrm{~cm}$ (12 in) deep by 10 $\mathrm{cm}$ (4 in) wide was opened with an AirSpade ${ }^{\mathrm{TM}}$ to expose roots at the edge of each walk on the side opposite the trees. A trench was opened at the same position for the four controls on each soil type without sidewalks. The distance between the soil surface and roots greater than $3 \mathrm{~mm}(0.1$ in) diameter was recorded in each trench. Average depth was calculated by summing all root depths and dividing by the number of roots. Number of roots in the top $10 \mathrm{~cm}$ (4 in) was recorded separately from deeper roots to determine if roots had grown upward after they grew under the $10 \mathrm{~cm}$ (4 in) thick sidewalks. Finding roots in the top $10 \mathrm{~cm}$ (4 in) would mean that roots grew up toward the soil surface after crossing under the walk. Trunk diameter was measured annually in winter.

A rebar $60 \mathrm{~cm}(2 \mathrm{ft}$ ) long was driven into the soil at the corner of each sidewalk section. The top of the rebar was positioned even with the top of the sidewalk. The vertical distance between the top of the rebar and the top of the sidewalks was measured in November 2003. This measurement was used to evaluate lift of the sidewalks that occurred at the end of the 7-year study.

Data were analyzed using ANOVA in a randomized complete block design with $P<0.05$ considered significant. Means were compared with Duncan's multiple range test.

\section{RESULTS}

Trunk diameter (28 cm [11.2 in]) 7 years after planting was not affected by root barrier treatments (i.e., trees grew at the same rate at both sites regardless of root barrier type). Trees with root barriers grew at the same rate as trees without barriers. Root number was weakly but significantly associated with trunk diameter in both the well-drained site $\left(R^{2}=0.24\right)$ and the poorly drained site $\left(R^{2}=0.34\right)$.

\section{Root Depth}

Simply installing a sidewalk deflected roots to deeper soil layers. The no sidewalk/no barrier treatment had significantly shallower average root depth (72 to $76 \mathrm{~mm}$ [2.9 to $3.0 \mathrm{in}])$ than trees growing with the sidewalk and no barrier (101 to $122 \mathrm{~mm}$ [4 to $4.9 \mathrm{in}$ ]) on both soil types (Table 1). In well-drained soil, average root depth was significantly greater under sidewalks with a gravel sub-base (194 mm [7.8 in]) than all other treatments (Table 1). There were no differences in root depth among any other root barrier treatments, nor was root depth in any other root barrier treatments different from the sidewalk without a barrier.

In the poorly drained site, the Biobarrier, gravel sub-base, and polyethylene treatments performed equally well; however, only the Biobarrier resulted in significantly deeper roots than the sidewalk without a barrier. Although Biobarrier produced significantly deeper roots, these roots were only 16 $\mathrm{mm}$ (0.6 in) deeper than those under the sidewalk without a barrier. In practice, this difference might not be large enough to distinguish it from sidewalks without barriers. Conversely, roots in the Deep Root treatment were significantly closer to the soil surface than those of the sidewalk without a barrier, 
Table 1. Average depth $(\mathrm{mm})$ and range in depth (in parentheses) of sycamore roots (roots $>5 \mathrm{~mm}$ [0.3 in] diameter) in the top $30 \mathrm{~cm}$ (12 in) of soil adjacent to sidewalks with various root barriers in two soil types.

\begin{tabular}{lll}
\hline Treatment & Well-drained soil & Poorly drained soil \\
\hline No sidewalk/no barrier & $76 \mathrm{c}^{*}(25-170)$ & $72 \mathrm{~d}(13-195)$ \\
Sidewalk/no barrier & $101 \mathrm{~b}(33-180)$ & $122 \mathrm{~b}(55-248)$ \\
Sidewalk/Biobarrier@ & $107 \mathrm{~b}(20-245)$ & $138 \mathrm{a}(65-275)$ \\
Sidewalk/Deep Root & $117 \mathrm{~b}(35-235)$ & $105 \mathrm{c}(50-223)$ \\
Sidewalk/gravel sub-base & $194 \mathrm{a}(109-306)$ & $131 \mathrm{ab}(0-230)$ \\
Sidewalk/polyethylene & $108 \mathrm{~b}(37-223)$ & $131 \mathrm{ab}(65-235)$
\end{tabular}

Statistical significance

Treatments $\quad P<0.0001$

Soil type ns

Treatments $\times$ soil type $\quad P<0.0001$

"Means in a column with a different letter indicate a significant difference at $P<0.05$ with Duncan's MRT. Means were calculated by averaging the distance between the root and soil surface of all roots encountered at the edge of the walk.

Note: All treatments had a $1.2 \mathrm{~m}$ (4 ft) wide sidewalk installed $0.6 \mathrm{~m}$ $(2 \mathrm{ft})$ away except where indicated. Barriers were on same side of the sidewalk as the tree; root excavations were done at the edge of the other side of the walk.

but only by $17 \mathrm{~mm}$ ( $0.7 \mathrm{in})$. Again, the real-world significance of this difference is probably negligible.

\section{Root Diameter}

There was no difference in average root diameter between soil types (Table 2). Root diameter was similar among all treatments on the poorly drained soil. However, on welldrained soil, diameter of roots at the edge of the sidewalks with gravel sub-base was significantly less than with the controls. The larger-diameter roots may have been deeper than $30 \mathrm{~cm}$ (12 in).

\section{Root Number}

Trenches adjacent to sidewalks in the poorly drained site had a greater number of roots than in the well-drained site (Table 3). In well-drained soil, only the gravel sub-base treatment resulted in fewer roots in the top $30 \mathrm{~cm}$ (12 in) of soil than sidewalks without barriers (Table 3 ). In poorly drained soil, all treatments resulted in significantly fewer roots in the top $30 \mathrm{~cm}$ (12 in) of soil than sidewalks without barriers.

In well-drained soil, the gravel sub-base treatment resulted in no roots (0\%) in the top $10 \mathrm{~cm}$ (4 in) of soil at the edge of the sidewalk (Table 3). This was the only treatment with significantly fewer roots in this top layer than the sidewalks without a barrier. The Deep Root, polyethylene, and Biobarrier treatments followed with 35\%,39\%, and $49 \%$ of their roots within this top layer, respectively. In poorly drained soil, Biobarrier and gravel sub-base had 15\% and $17 \%$ of their roots, respectively, in the top $10 \mathrm{~cm}$ (4 in)
Table 2. Average diameter $(\mathrm{mm})$ and range in diameter (in parentheses) of sycamore roots $(>3 \mathrm{~mm}$ [0.1 in] diameter) in the top $30 \mathrm{~cm}$ (12 in) of soil adjacent to sidewalks with various root barriers in two soil types.

\begin{tabular}{lll}
\hline Treatment & Well-drained soil & Poorly drained soi \\
\hline No sidewalk/no barrier & $7.2 \mathrm{a}^{*}(3-31)$ & $6.8 \mathrm{a}(3-43.5)$ \\
Sidewalk/no barrier & $7.2 \mathrm{a}(3-32)$ & $6.4 \mathrm{a}(3-35.6)$ \\
Sidewalk/Biobarrier & $5.0 \mathrm{ab}(3-18.1)$ & $6.2 \mathrm{a}(3-17.4)$ \\
Sidewalk/Deep Root & $6.5 \mathrm{ab}(3-39.8)$ & $6.9 \mathrm{a}(3-80)$ \\
Sidewalk/gravel sub-base & $4.7 \mathrm{~b}(3-7.9)$ & $7.0 \mathrm{a}(3-47.4)$ \\
Sidewalk/polyethylene & $5.4 \mathrm{ab}(3-13.3)$ & $6.4 \mathrm{a}(3-39.4)$
\end{tabular}

Statistical significance

Treatments ns

Soil type ns

Treatments $\times$ soil type $\quad P<0.04$

"Means in a column with a different letter indicate a significant difference at $P<0.05$ with Duncan's MRT.

Note: All treatments had a $1.2 \mathrm{~m}(4 \mathrm{ft})$ wide sidewalk installed $0.6 \mathrm{~m}$ $(2 \mathrm{ft})$ away except where indicated. Barriers were on same side of the sidewalk as the tree; root excavations were done at the edge of the other side of the walk.

of soil. This was significantly less than the number under the sidewalk without a barrier. The percentage of roots in the top $10 \mathrm{~cm}$ (4 in) in polyethylene (21\%) and Deep Root (46\%) treatments was not different from that of the sidewalk without a barrier (29\%).

\section{DISCUSSION}

The three vertical root barriers studied all showed varying degrees of success in poorly drained soil, with Biobarrier appearing most effective at deflecting roots deeper below the surface. Previous studies (Barker 1995a, 1995b; Gilman 1996; Harris et al 2004) suggest that vertical barriers might work best in soils that least require them, such as welldrained, noncompacted soils. But in the current study, the vertical barriers did not result in deeper root systems in welldrained soil. Perhaps deeper vertical barriers would have resulted in a different outcome. Only the gravel sub-base was effective in well-drained soil. Additional research is needed to further clarify the utility of barriers in different soil types.

Deep Root barriers and polyethylene barriers $30 \mathrm{~cm}$ (12 in) deep were not effective at reducing root growth in the top $10 \mathrm{~cm}$ (4 in) soil layer in either soil type. The inconsistency of vertical root barriers of all types has been previously documented, as many investigators have noted that roots grow toward the surface after they pass underneath a barrier (Wagar 1985; Gilman 1996; Nicoll and Coutts 1998; Peper 1998; Peper and Mori 1999). Thus, roots grew up near the soil surface and/or under the sidewalks within a few meters of the barrier, presumably in response to finding improved conditions at the shallow soil depths. Perhaps 
Table 3. Number ${ }^{z}$ of sycamore roots ( $>5 \mathrm{~mm}[0.3 \mathrm{in}]$ diameter) occurring at different depths adjacent to sidewalks with various root barriers in two soil types. Percentage of sycamore roots $(>5 \mathrm{~mm}[0.3 \mathrm{in}]$ diameter) occurring at different depths is indicated in parentheses.

\begin{tabular}{|c|c|c|c|c|c|}
\hline Depth from soil surface & No barrier & Biobarrier $^{\mathrm{TM}}$ & Deep Root ${ }^{\mathrm{TM}}$ & Gravel & Polyethylene \\
\hline \multicolumn{6}{|l|}{ Well-drained soil } \\
\hline$\leq 10 \mathrm{~cm}$ & $34 b^{y}(50)$ & $34 \mathrm{~b}(48.6)$ & $17 \mathrm{~b}(35.4)$ & $0 \mathrm{a}(0)$ & $22 \mathrm{~b}(39.3)$ \\
\hline$>10-30 \mathrm{~cm}$ & 34 a (50) & $36 \mathrm{a}(51.4)$ & 31 a (64.6) & $23 \mathrm{a}(100)$ & $34 \mathrm{a}(60.7)$ \\
\hline Total number & $68 \mathrm{~b}$ & $70 \mathrm{~b}$ & $48 \mathrm{~b}$ & $23 a$ & $56 \mathrm{~b}$ \\
\hline \multicolumn{6}{|l|}{ Poorly drained soil } \\
\hline$\leq 10 \mathrm{~cm}$ & 42 b (29) & $11 \mathrm{a}(15.3)$ & $38 \mathrm{~b}(45.8)$ & $15 \mathrm{a}(16.8)$ & $20 \mathrm{ab}(20.8)$ \\
\hline$>10-30 \mathrm{~cm}$ & 103 a (71) & $61 \mathrm{a}(84.7)$ & $45 \mathrm{a}(54.2)$ & $74 \mathrm{a}(83.2)$ & $76 \mathrm{a}(79.2)$ \\
\hline Total number & $145 \mathrm{~b}$ & $72 \mathrm{a}$ & $83 a$ & 89 a & 96 a \\
\hline \multicolumn{6}{|l|}{ Statistical significance } \\
\hline Treatments & $P<0.05$ & & & & \\
\hline Soil type & $P<0.05$ & & & & \\
\hline Treatments $\times$ soil type & $P<0.04$ & & & & \\
\hline
\end{tabular}

${ }^{z}$ Means were calculated on four tree-sidewalk pairs per treatment. Sidewalks were $10 \mathrm{~cm}$ (4 in) thick.

${ }^{y}$ Numbers in a row and within a soil drainage type with different letters indicate significant difference at $P<0.05$ with Duncan's MRT.

deeper barriers could protect sidewalks better than the 30 $\mathrm{cm}$ (12 in) deep barriers used in the current study, but few direct comparisons have been made.

The dramatic success of the gravel layer on the welldrained soil may be attributed to the air space between gravel particles. Unlike structural soils that encourage root growth between gravel particles due to the presence of soil between aggregates (Grabosky and Bassuk 1996), the drying nature of air between particles of gravel in our study did not allow roots to grow there. Tree growers have taken advantage of this phenomenon by designing containers with air holes in the sides to reduce root circling (Marshall and Gilman 1998). Gravel was not effective in forcing roots deeper in poorly drained soil, probably because the low oxygen content of the soil environment at deeper depths was ill suited for root growth.

One sidewalk in the control without a barrier on the well-drained soil was lifted $3 \mathrm{~cm}$ (1.2 in) and cracked at the position of a large-diameter $32 \mathrm{~mm}$ (1.3 in) root. We could not determine whether the crack appeared first and the root then grew in response to the oxygen entering the crack or if the root grew there first and caused the crack. Others (Sydnor et al. 2000) found that sidewalks on clay soils were just as likely to crack with or without trees nearby. This issue needs more research on different soil types. Other sidewalks were lifted, but there was no significant difference in lifting among treatments or soil types (data not shown).

\section{SUMMARY}

The gravel layer proved the most effective at keeping roots well under the bottom of the sidewalk slab. Although the effect was most prominent in the well-drained soil type, gravel also performed fairly well in the poorly drained soil, at least as well as vertical barriers. Biobarrier was effective only in the poorly drained soil. The polyethylene and Deep Root barriers did not encourage significantly deeper roots or fewer roots in the top $10 \mathrm{~cm}$ (4 in) layer of soil than the control in either soil type.

\section{LITERATURE CITED}

Barker, P.A. 1995a. Managed development of tree roots. I. Ultra-deep rootball and root barrier effects on European hackberry. Journal of Arboriculture 21:202-208.

_ 1995b. Managed development of tree roots. II. Ultradeep rootball and root barrier effects on southeastern black cherry. Journal of Arboriculture 21:251-259.

Bernhardt, E., and T.J. Swiecki. 1993. The State of Urban Forestry in California-1992. California Department of Forestry and Fire Protection Urban Forestry Program, Sacramento, CA.

Coder, K. 1998. Root growth control: Managing perceptions and realities, pp. 51-81. In Neely, D., and G.W. Watson (eds.). The Landscape Below Ground II: Proceedings of an International Workshop on Tree Root Development in Urban Soils. International Society of Arboriculture, Champaign, IL.

Costello, L., and K. Jones. 2003. Reducing Infrastructure Damage by Tree Roots: A Compendium of Strategies. Western Chapter ISA, Cohasset CA.

Costello, L.R., C.L. Elmore, and S. Steinmaus. 1997. Tree root response to circling root barriers. Journal of Arboriculture 23:211-218. 
Francis, J.K., B.P. Parresol, and J.M. de Patino. 1996. Probability of damage to sidewalks and curbs by street trees in the tropics. Journal of Arboriculture 22:193197.

Gilman, E.F. 1996. Root barriers affect root distribution. Journal of Arboriculture 22:151-154.

Grabosky, J., and N. Bassuk. 1996. Testing of structural urban tree soil materials for use under pavement to increase street tree rooting volumes. Journal of Arboriculture 21:197-201.

Harris, R.W., J.R. Clark, and N.P. Matheny. 2004. Arboriculture: Integrated Management of Landscape Trees, Shrubs, and Vines (4th ed.). Prentice Hall, Upper Saddle River, NJ.

Kopinga, J. 1994. Aspects of the damage to asphalt road pavings caused by tree roots, pp. 165-178. In Watson, G.W., and D. Neely (eds.). The Landscape Below Ground. Proceedings of an International Workshop on Tree Root Development in Urban Soils. International Society of Arboriculture, Champaign, IL.

Marshall, M., and E.F. Gilman. 1997. Production method and irrigation affect root morphology of live oak. Journal of Environmental Horticulture 15:84-87.

- 1998. Effects of nursery container type on root growth and landscape establishment of Acer rubrum L. Journal of Environmental Horticulture 16:55-59.

Nicoll, B.C., and M.P. Coutts. 1998. Deflection of Tree Roots by Rigid Barriers. Arboriculture Research and Information Note. 143/98/SILN. Arboriculture Advisory and Information Service, Surrey, England.

Peper, P. 1998. Comparison of root barriers installed at two depths for reduction of white mulberry roots in the soil surface, pp. 82-93. In Neely, D., and G.W. Watson (eds.). The Landscape Below Ground II: Proceedings of an International Workshop on Tree Root Development in Urban Soils. International Society of Arboriculture, Champaign, IL.
Peper, P., and S. Mori. 1999. Controlling root depth of posttransplant trees: Extension casing and root barrier effects on Chinese hackberry. Journal of Arboriculture 25:1-8.

Rajani, B. 2002. Behavior and Performance of Concrete Sidewalks: Construction Technology Update \#54. Institute for Research in Construction, National Research Council of Canada, Ottawa, ON.

Randrup, T.G., E.G. McPherson, and L.R. Costello. 2001. A review of tree root conflicts with sidewalks, curbs and roads. Urban Ecosystems 5:209-225.

Sydnor, T.D., D. Gamestetter, J. Nichols, B. Bishop, J. Favorite, C. Blazer, and L. Turpin. 2000. Trees are not the root of sidewalk problems. Journal of Arboriculture 26:20-24.

Wagar, J.A. 1985. Reducing surface rooting of trees with control planters and wells. Journal of Arboriculture 11:165-171.

Wagar, J.A., and P.A. Barker. 1983. Tree root damage to sidewalks and curbs. Journal of Arboriculture 9:177181.

. 1993. Effectiveness of three barrier materials for stopping regenerating roots of established trees. Journal of Arboriculture 19(6):332-338.

United States Department of Agriculture (USDA). 1990. USDA Plant Hardiness Zone Map. USDA Miscellaneous Publication No. 1475. www.usna.usda.gov/Hardzone/ ushzmap.html (accessed 11/30/05).

Acknowledgments. Florida Agricultural Experiment Station Journal Series number R-10809. Thanks to the Great Southern Tree Conference and Reemay Corporation for partial funding.

Edward F. Gilman

Professor

University of Florida

Gainesville, FL 32611, U.S. 
Résumé. Des trottoirs en béton de $10 \mathrm{~cm}$ d'épaisseur, de 1,2 m de largeur et $5 \mathrm{~m}$ de longueur ont été construits en 1995 avec et sans barrière conçues pour dévier la croissance des racines. Quarante-huit Platanus occidentalis produits en contenants no 15 ont été plantés à 0,75 m de distance des trottoirs et arrosés régulièrement pour favoriser une croissance rapide. Des protocoles similaires d'étude ont été construits sur un site bien drainé et un site mal drainé localisés à $18 \mathrm{~km}$ l'un de l'autre. Les barrières utilisées ont été le DeepRoot de $30 \mathrm{~cm}$ de profondeur, le Biobarrier®, un polyéthylène de 6 millième, une couche de $15 \mathrm{~cm}$ d'épaisseur de gravier net de 2 à $3 \mathrm{~cm}$ de diamètre sous le trottoir et un groupe-témoin sans barrière antiracinaire. Les racines ont été excavées huit années après la plantation. Dans le site bien drainé, aucune racine n'avait poussé dans la couche de gravier, ce qui a donné un système racinaire significativement plus profond $(19 \mathrm{~cm})$ sous le trottoir par rapport à tous les autres types de traitement (11 $\mathrm{cm})$. Les barrières verticales n'ont pas permis d'accroître la profondeur d'enracinement comparativement au groupe-témoin au sein du sol bien drainé. La couche de gravier sous le trottoir et le Biobarrier étaient les plus efficaces dans le cas du site mal drainé. Le DeepRoot était la barrière verticale la moins effective dans le site mal drainé et le Biobarrier la plus efficace. Les divers traitements n'avaient aucune influence sur le diamètre des racines qui ont poussé sous les trottoirs. Les racines déviées par les barrières verticales ont été forcées de croître plus profondément dans le sol, mais plusieurs ont retourné vers la surface dès qu'elles se sont retrouvées de l'autre côté du trottoir. La couche de gravier sous le trottoir semble être prometteuse pour diminuer les dommages, plus spécifiquement dans le cas des sites bien drainés.

Zusammenfassung. Im Frühjahr 1995 wurden Betonseitenstreifen mit den Maßen 0,1 m x 1,2 m x 5,0 m mit und ohne Wurzelbarrieren installiert. 48 Platanen (Platanus occidentalis) aus Containern wurden in 0,75 m Abstand vom Betonstreifen gepflanzt und regelmäßig bewässert, um das Wachstum zu unterstützen. Es wurden 2 identische Studien auf einem gut drainierten und einem schlecht drainierten Standort mit $18 \mathrm{~km}$ Distanz durchgeführt. Die Barrieren bestanden aus $30 \mathrm{~cm}$ DeepRoot, Biobarrier ${ }^{\circledR}$, Poyethylen, $15 \mathrm{~cm}$ tiefen Schotter unter dem Beton und einer Kontrolle ohne Barriere. 8 Jahre nach der Pflanzung wurden die Wurzeln ausgegraben. Es gab kein
Wurzelwachstum in dem Schotter auf den gut drainierten Standorten, da sich die Wurzeln entsprechend tiefer ausbreiten konnten. Die vertikalen Wurzelbarrieren steigerten nicht die Wurzeltiefe, verglichen mit der Kontrolle auf den gut drainierten Böden. Schotter unter dem Beton und Biobarrier ${ }^{\mathrm{TM}}$ waren am effektivsten auf schlecht drainierten Böden. DeepRoot war die schlechteste Lösung auf diesen Böden, Biobarrier die beste Lösung. Die Behandlungen hatten keinen Einfluß auf den

Wurzeldurchmesser unterhalb des Betons. Die Wurzeln, die durch vertikale Barrieren behindert wurden, wuchsen zunächst tiefer in den Boden, aber kehrten dann, wenn sie den Betonsteg passiert hatten wieder zu Oberfläche zurück. Schotter unter dem Beton schien erfolgreich bei der Reduzierung von Gehwegschäden, besonders auf gut drainierten Standorten.

Resumen. Se instalaron aceras de concreto de $10 \mathrm{~cm}$. de grosor, $1.2 \mathrm{~m}$ de ancho por $5 \mathrm{~m}$ de largo en la primavera de 1995, con y sin deflectores de raíces. Cuarenta y ocho Platanus occidentalis fueron plantados a $0.75 \mathrm{~m}$ de distancia de las aceras y se regaron regularmente para estimular un rápido crecimiento. Estudios idénticos fueron instalados en dos sitios separados $18 \mathrm{Km}$. (11.2 miles) el uno del otro, uno de los sitios tenía buen drenaje y el otro mal drenaje. Las barreras incluyeron a $30 \mathrm{~cm}$. (12 in) de profundidad DeepRooT, Biobarrier ${ }^{\circledR}$, polietileno (6 mil), una capa de $15 \mathrm{~cm}$. de grava limpia $(2-3 \mathrm{~cm}$. de diámetro) bajo la acera, y un control sin barrera. Las raíces fueron excavadas 8 años después de la plantación. Ninguna raíz creció en la grava del sitio bien drenado, dando lugar a un sistema de raíces significativamente más profundo [19 cm. (8 in)] bajo las aceras que todos los otros tratamientos $[11 \mathrm{~cm}$. (4 in)]. Las barreras verticales no incrementaron la profundidad de la raíz comparadas con el control en el suelo bien drenado. La grava bajo la acera y Biobarrier fueron los más efectivos en el suelo mal drenado. DeepRoot fue la barrera vertical menos efectiva en un suelo pobremente drenado, Biobarrier fue la más efectiva. Los tratamientos no tuvieron efecto en el diámetro de las raíces que crecen bajo las aceras. Las raíces desviadas por barreras verticales fueron forzadas a profundizarse en el suelo, pero muchas regresaron a la superficie cuando alcanzaron el lado opuesto de la acera. La grava bajo la acera parece cumplir con la promesa de reducir el daño a las aceras, especialmente en los sitios bien drenados. 